\title{
The Implementation of QR-Code Technology on Bulak Fish Center Information System
}

\author{
Febri Liantoni ${ }^{1}$, Septiyawan Rosetya ${ }^{2}$, Weny M. Rahmawati ${ }^{3}$ \\ 1,2,3 Informatics Department, Faculty of Information Technology \\ Institut Teknologi Adhi Tama Surabaya, Surabaya, Indonesia \\ ${ }^{1}$ febri.liantoni@mail.ko2pi.org, ${ }^{2}$ rossywardhana@gmail.com, ${ }^{3}$ wenymistarika@gmail.com
}

\begin{abstract}
The technology that is currently developing is the use of QR-Code. QR-Code can convey information quickly with the acquisition of fast responses as well. QR-Code can be used on smartphones. Some media and companies widely use the QR-Code in Indonesia. QR-Code is not only used as an application identity but is also used as a means of effective, simple and modern business promotion. Making information systems for Sentra Ikan Bulak Surabaya is done by using QR-Code technology as a means of product promotion in the sales process. Research that has been done can run well and can support and be useful in improving the means of promotion. Traders find it easier to collect data on existing systems. Buyers can access the site and see reviews from other buyers so buyers will feel interested in buying the product.
\end{abstract}

Keywords- QR-Code, Site, Technology

\section{INTRODUCTION}

The increasing technological developments can benefit the community industry. With the development of these technologies will certainly affect the lifestyle and habits of society - the growing age, more and more sophisticated inventions that can facilitate the conduct of all community activities. Various conveniences can be done using technology. One of the benefits of using technology for the community is through the website information system. Through the information system, the community can promote products that are produced more efficiently and can introduce it to all corners of the world. Through information technology can provide opportunities in marketing products or services. Attractive web features are one of the good and cheaper promotional tools, especially in the service business. In principle, the role of technology in marketing is as a tool to simplify the process, behind which human resources and marketing strategies remain the main key. With the facility of advertising on the internet on certain sites will facilitate the promotion and marketing of a product. Can make it easier to do business online that can be accessed easily and quickly.

The promotion stage is a determining factor for the success of a process in marketing, so promotion is very important in the buying and selling process. Products are tangible or intangible attributes, in which there are colors, prices, names of goods and the name of the shop that sells them, which is accepted by the buyer to satisfy his desires. Products, prices, promotions, distribution channels, and Reference groups have a significant effect on purchasing decisions[1].

However, rapid technological developments cannot be followed by all levels of society especially when you have to operate directly. Many sellers have difficulty accessing technology to promote the products they produce. One technology that supports the operation of information systems more easily is the use of a barcode or quick response code (QR-Code). QR-Code has become part of human life. Because information technology has developed rapidly, QR-Code is used for various purposes, one of which is for internet marketing[2]. The QR-Code method has a smaller display than the barcode and is accessed through a mobile device that is connected to a database system that records identity data [3][4]. Unlike the bar code, which only stores information horizontally, QR codes can store information horizontally and vertically[5]. By using the QR-Code, we can accommodate a lot of product information in the information system more easily.

This study proposes the application of QR-Code technology in the information system of the Surabaya Bulak Fish Center. QR-Code technology is used to access information systems to add products produced by sellers.

\section{METHOD}

In the research carried out there are several steps taken. The method of approach in the phase of research that will be carried out to achieve predetermined goals, among others, survey to determine the conditions at the Bulak Fish Center in Surabaya. Improve the performance of the sellers by providing training on the use of a web-based Sales Information System. Procurement of training and practice and materials on how to use a web-based Sales Information System.

The steps in this research start from collecting literature study, data collection, requirement analysis based on data collection, building information system, testing, training and applying the information system to be used in Bulak Fish Center, the phase can be seen in Figure 1. 


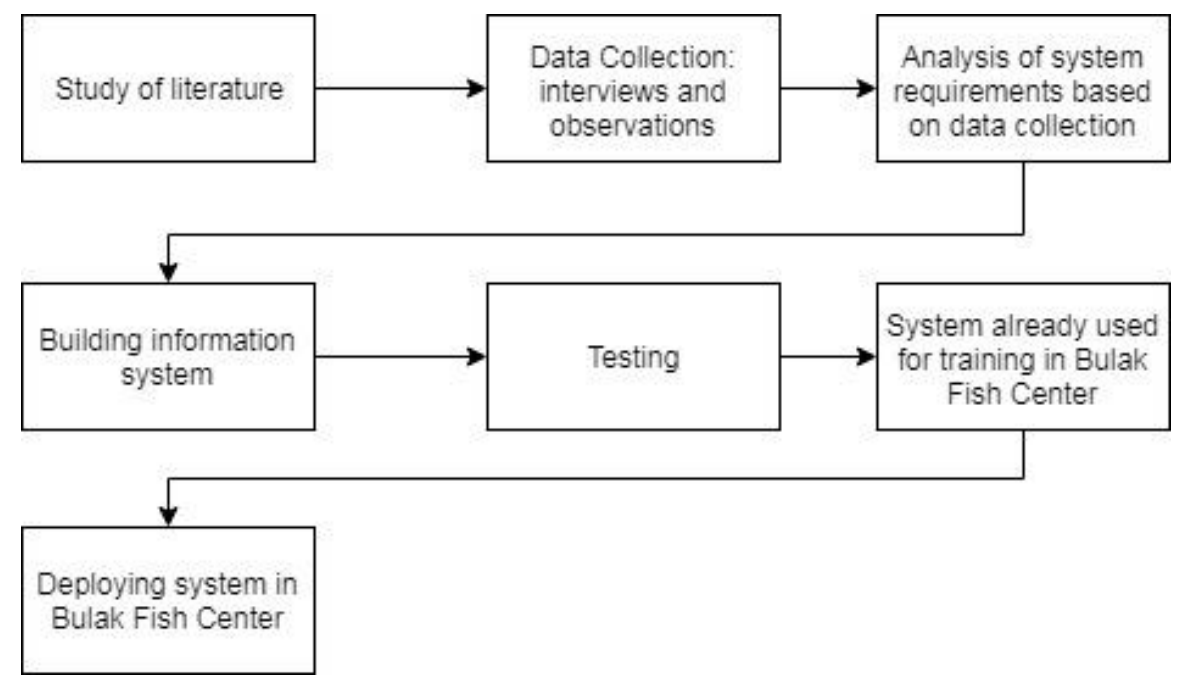

Figure 1. Phase of Research

The training is carried out such as the use of a QR-Code intended to enter a link with the QR-Code card that has been provided, a card to enter as a member of the seller and a product card. Membership cards are owned by each seller that has been registered on the website as a seller at the Bulak Fish Center. Insert training and product stock updates are given to member sellers on the website, which is about how to increase or decrease the stock of products owned by each seller. This admin training is given to an admin who has full rights to the website created. Admin is in charge of managing the entire website of the Bulak fish centre.

\section{A. QR-Code (Quick Response Code)}

QR-Code stands for Quick Response Code, a type of code matrix or two-dimensional barcode created and developed by Denzo Wave in 1994, which at that time was a division of Denso Corporation, a Japanese company that is still part of the Toyota Group[5][6]. Initially, the QR-

Code was used to record vehicle spare parts within the company, but now the usage is getting wider, even though the QR-Code specification is released to the public. Currently, the use of two-dimensional barcodes is very broad but generally used to encode website addresses, contact numbers, e-mail addresses, telephone numbers or just plain text.

The QR-Code has two sides that contain data. This makes the QR-Code contain more information than the bar code. QR-Code can directly scan and enter the website in question without the need to type the address. Another use of QR-Code is to store text data about product information or other things. The tool used to read QR-Code is called QR-Code Scanner. Generally, this tool is not a separate tool but is available in the form of applications on smartphones such as Android or iPhone.
The main purpose of the QR-Code is currently used to make it easier for users to access information in two easy steps, namely, scan the QR-Code and take action. Taking action can be in the form of opening a browser, saving contact information or dialling a number in the QR-Code.

The benefits of QR-Code in smartphones are easy to access to information. How to read the QR-Code is very easy, which is to turn on the QR-Code scanner feature and then direct the smartphone camera on the $\mathrm{QR}$ to be accessed while cellphones that do not have a camera must access the browser and enter the seven digit ID printed at the bottom of the QR-Code.

QR-code as a fast method of disseminating information can be used to replace learning modules, store movie or video information and this is a good and smart positive step [7]. QR-code ability to accommodate a lot of information even in small sizes. The QR-Code structure can be seen in Figure 2.

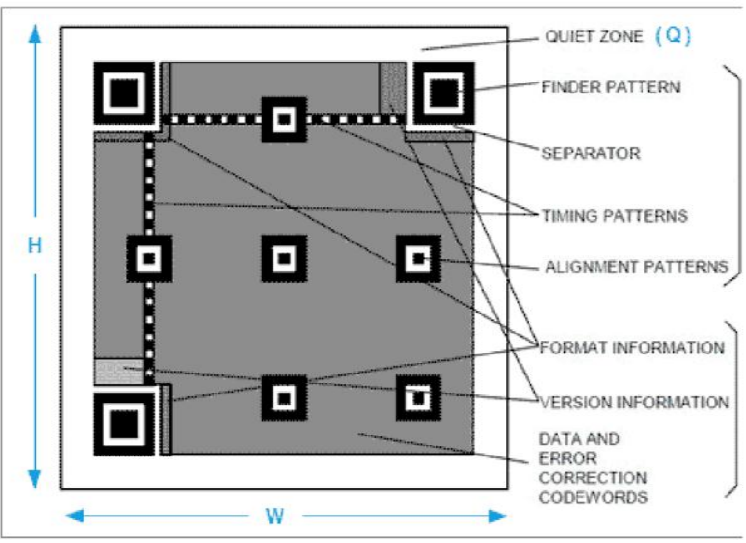

Figure 2. 2D QR Code structure (ISO/IEC18004, 2006)[8] 
The International Standards Organization and the International Electrotechnical Commission (ISO / IEC) have published two standards since 2000 . The first version (ISO / IEC 18004: 2000) was published in 2000 and the second version (ISO / IEC 18004: 2006) in 2006 revised the version first[8]. The examples of technological forms from the QR-Code are show on the following figure:

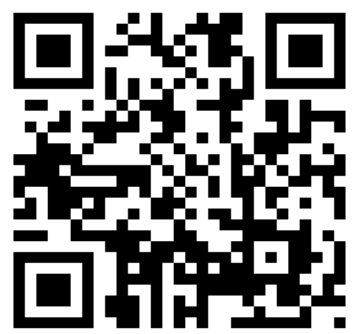

Figure 3. QR-Code Version 40[9]

B. Web Based Information System

Web writing is an interconnected page generally located in the same service containing a collection of information provided by individuals, groups or organizations. A website is usually placed at least on a web server that can be accessed through a network such as an internet, or a local area network (LAN) through an internet address that is recognized as a URL. Combined all sites that can be accessed publicly on the internet are also referred to as the World Wide Web, or better known as the abbreviation WWW.

The web-based information system is an information system that uses web or internet technology to provide information and services to users or other information systems[10]. The web information system usually consists of one or more web applications, each of which has a specific function. Where each - each component supports each other to achieve the function of a web-based information system in general. General description of the application of web-based information systems in research such as figure 4 .

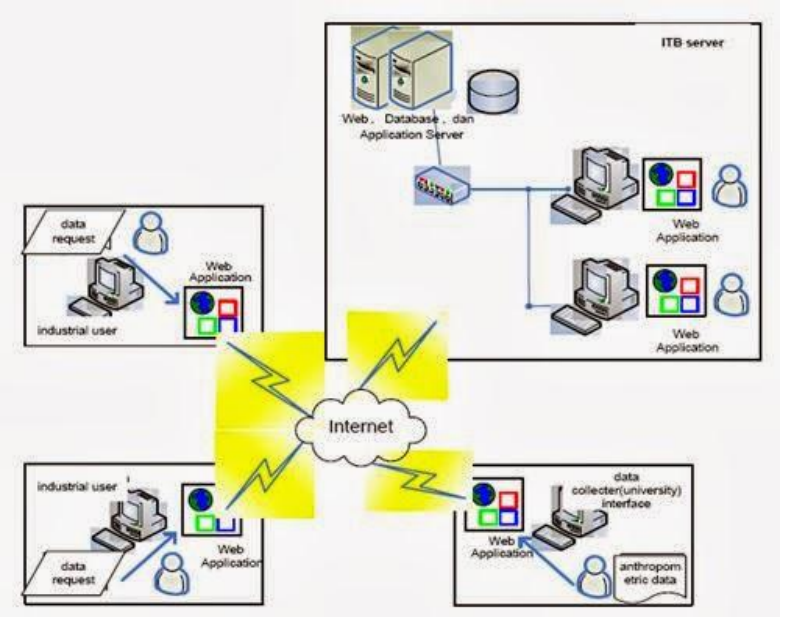

Figure 4. Web-Based Information System

\section{RESULT AND DISCUSSION}

Many sellers can use the results of the product promotion information system design as a medium for delivering information and introducing products produced to the public. The website that has been made the address at the link http://sentraikanbulak.com. The system is seen in figure 5 .

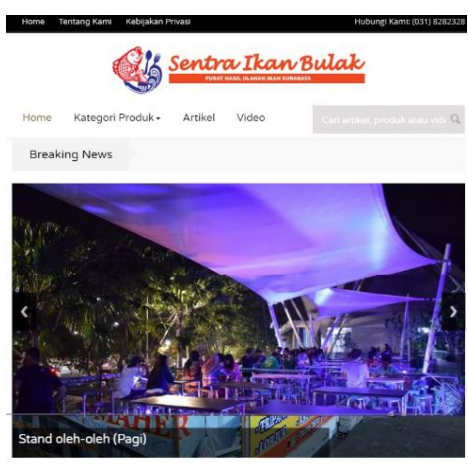

Daftar Produk
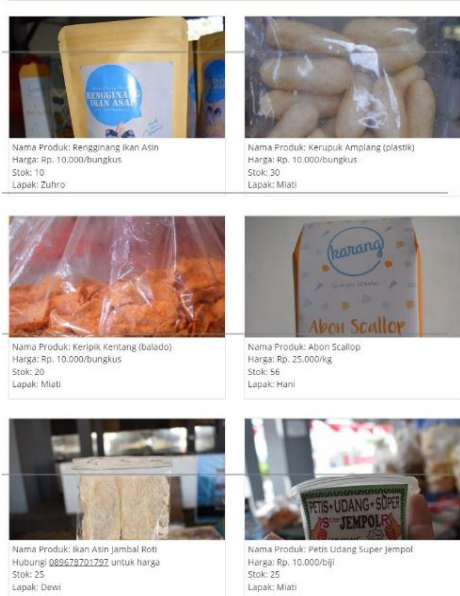

Figure 5. A Web Page of Sentra Ikan Bulak

Figure 5 displays a system that can be seen by anyone without going through the login process. The seller must log in using a QR-Code card in order to add merchandise. The login process is shown in figure 6 .
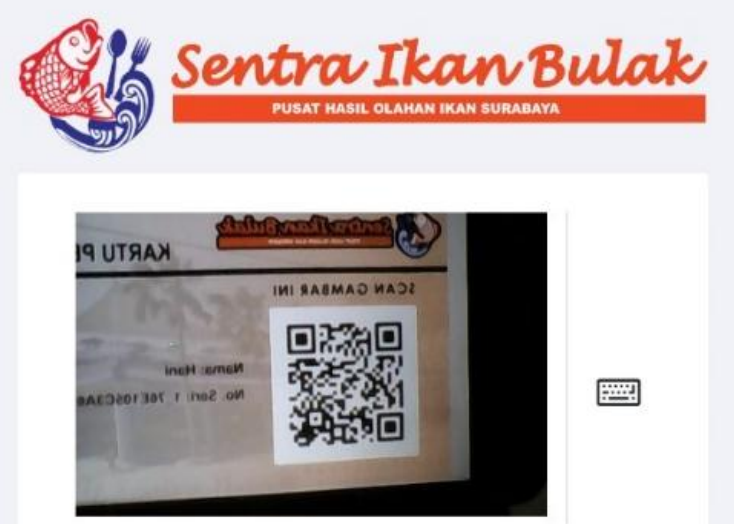

Figure 6. Use of cards with QR-Code 
After the seller login to system, the seller can then add the products produced on the system, so that they can be displayed and viewed by consumers. In addition, sellers can also change the amount of stock when there is an increase in inventory. To add stock and product prices, sellers must also use a QR-Code card. This method is done to simplify the process of finding the appropriate product. An example of the process of increasing the amount of stock is shown in Figure 7.

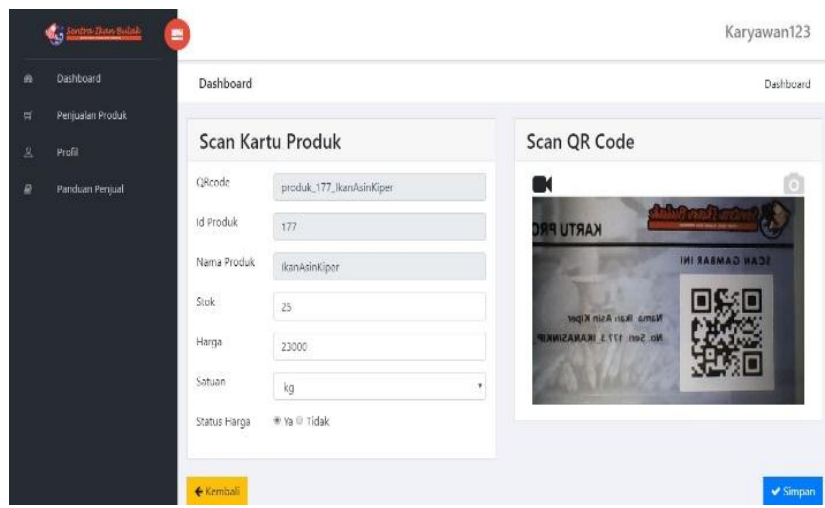

Figure 7. Additions of stock and prices based on cards

The example page to see the trading product data is shown in figure 8 .
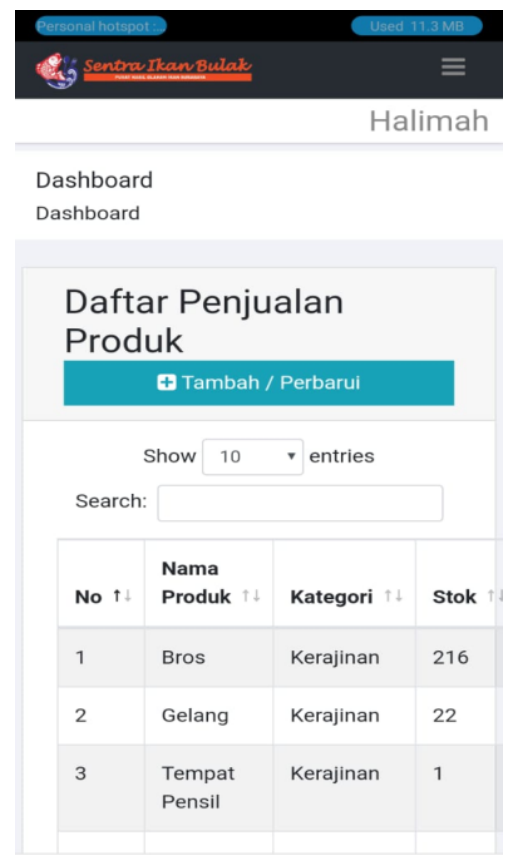

Figure 8. List of Product

The training was also conducted to the admin for the Surabaya Bulak Fish Center. Training for admin aims that the system admin can better manage the site, such as to manage and register the seller. The seller list registered in the system is shown in Figure 9.
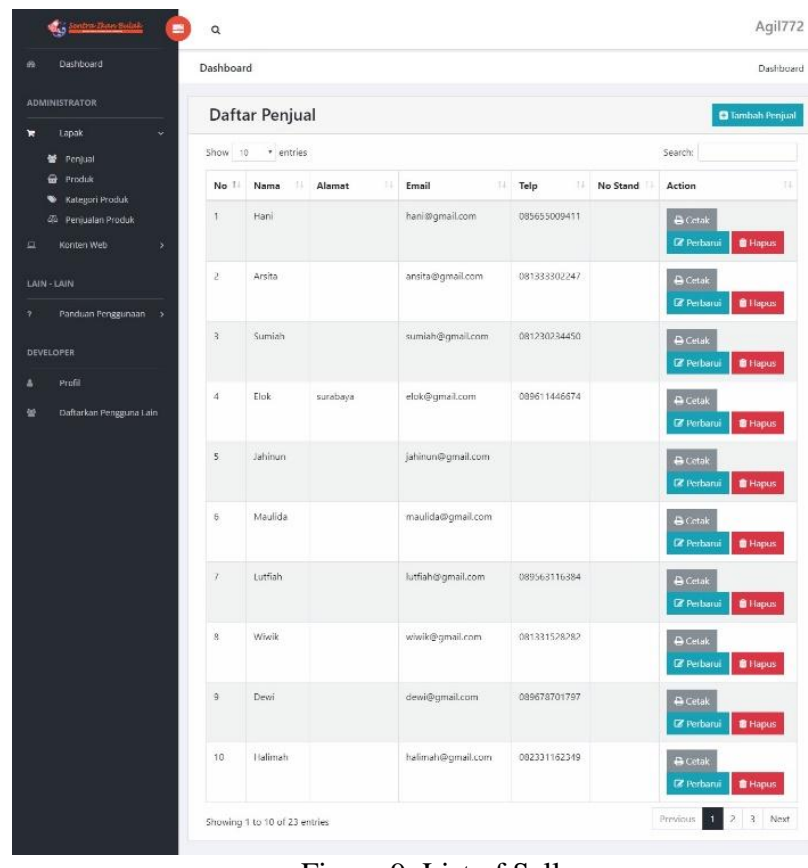

Figure 9. List of Seller

Based on the research that has been done using the QRCode in the management process the web system shows benefits that are meaningful to the seller. The sellers are easier to run the system using QR-Code. The seller does not have to type a username and password when logging in to the system. To change the stock and prices of seller's products also easily use QR-Code cards without looking for products sold. The system can easily manage products based on QR-Code that have been registered. In addition, the system is also made in increasing promotional facilities.

\section{IV.CONCLUSION}

Based on the evaluation results of the Surabaya Bulak Fish Center information system using QR-Code technology, it can simplify running the system and provide youth in the management of merchandise. The sellers are easier to do data collection on existing systems. The making of the system is also able to improve the means of promoting handicraft products.

\section{REFERENCES}

J. Prasetyo, "Pengaruh Produk, Harga, Promosi, Saluran Distribusi Dan Kelompok Referensi Terhedap Keputusan Pembelian Sepeda Motor Honda Vario Di Kota Pontianak," J. Manaj. Updat., vol. 5, no. 1, Jan. 2016.

[2] S. Demir, R. Kaynak, and K. A. Demir, "Usage Level and Future Intent of Use of Quick Response (QR) Codes for Mobile Marketing among College Students in Turkey," Procedia - Soc. Behav. Sci., 
vol. 181, pp. 405-413, May 2015.

[3] M. Pérez-Sanagustín, D. Parra, R. Verdugo, G. García-Galleguillos, and M. Nussbaum, "Using QR codes to increase user engagement in museumlike spaces," Comput. Human Behav., vol. 60, pp. 73-85, Jul. 2016.

[4] N. A. Musthofa, S. Mutrofin, and M. A. Murtadho, "Inplementasi Quic Response (QR) Code pada Aplikasi Validasi Dokumen Menggunakan Perancangan Unified Modelling Language (UML)," ANTIVIRUS J. Ilm. Tek. Inform., vol. 10, no. 1, May 2016.

[5] B. Sugiantoro, "Pengembangan QR Code Scanner berbasis Android untuk Sistem Informasi Museum SonoBudoyo Yogyakarta," Telematika, vol. 12, no. 2, Jul. 2015.

[6] A. Avidan, C. Weissman, and P. D. Levin, "Integration of QR codes into an anesthesia information management system for resident case log management," Int. J. Med. Inform., vol. 84, no. 4, pp. 271-276, Apr. 2015.

[7] K. Gummesson, "Effective measures to decrease air contaminants through risk and control visualization - A study of the effective use of QR codes to facilitate safety training," Saf. Sci., vol. 82, pp. 120-128, Feb. 2016.

[8] ISO/IEC 18004, "Information technology -Automatic identification and data capture techniques -- QR Code 2005 bar code symbology specification," 2006. .

[9] F. Xu, QR-Code Encoding. Florida State University: Department of Scientific Computing, 2015.

[10] Supriyanta, W. Pudji, and S. Bekti, "Aplikasi Konversi Suara Ke Teks Berbasis Android Menggunakan Google Speech Api," Bianglala Inform., vol. 2, no. 2, pp. 11-19, 2014. 